\title{
Triggers of benign recurrent intrahepatic cholestasis and its pathophysiology: a review of literature
}

\author{
A. Halawi' ${ }^{1}$ N. Ibrahim², R. Bitar ${ }^{2}$ \\ (1) Department of Internal Medicine, Faculty of Medical Sciences, Lebanese University, Beirut, Lebanon; (2) Faculty of Medical Sciences, Lebanese University, Beirut, \\ Lebanon.
}

\begin{abstract}
Benign recurrent intrahepatic cholestasis (BRIC) is a rare genetic disorder that is characterized by episodes of cholestasis followed by complete resolution. The episodic nature of BRIC raises concerns about its possible trigger factors. Indeed, case reports of this orphan disease have associated BRIC to some triggers. In the absence of any reviews, we reviewed BRIC trigger factors and its pathophysiology. The study consisted of a systematic search for case reports using PubMed. Articles describing a clear case of BRIC associated with a trigger were included resulting in 22 articles that describe 35 patients. Infection was responsible for $54.3 \%$ of triggered episodes, followed by hormonal, drugs, and miscellaneous causes reporting as $30 \%, 10 \%$, and $5.7 \%$ respectively. Females predominated with $62.9 \%$. The longest episode ranged between 3 months to 2 years with a mean of 32.37 weeks. The mean age of the first episode was 14.28 ranging between 3 months to 48 years. Winter and autumn were the major seasons during which episodes happened. Hence, BRIC is potentially triggered by infection, which is most commonly a viral infection, hormonal disturbances as seen in oral contraceptive pills and pregnancy state, and less commonly by certain drugs and other causes. The appearance of cholestasis during the first two trimesters of pregnancy compared to intrahepatic cholestasis of pregnancy could help to differentiate between the two conditions. The possible mechanism of BRIC induction implicates a role of BSEP and ATP8B1. While estrogen, drugs, and cytokines are known to affect BSEP, less is known about their action on ATP8B1. (Acta gastroenterol. belg., 2021, 84, 477486).
\end{abstract}

Key words: Intrahepatic cholestasis, Benign recurrent intrahepatic cholestasis, FIC1 protein, BSEP protein.

\section{Introduction}

Benign recurrent intrahepatic cholestasis (BRIC), a rare genetic disease of unknown prevalence, was described for the first time in 1959 by Summerskill and Walshe (1). BRIC is considered as part of a bigger family, familial intrahepatic cholestasis (FIC) which is composed of progressive familial intrahepatic cholestasis (PFIC) 1, 2 and 3, as well as BRIC 1 and 2 (2,3). These phenotypes share many common genes: Familial intrahepatic gene (FIC)/ ATP8B1 (ATPase phospholipid transporting 8B1) gene responsible for BRIC 1 and PFIC 1, ABCB11 (ATP-binding cassette, sub-family B member 11) gene associated with BRIC 2 and PFIC 2, and ABCB4 associated with PFIC 3 (2-4). A defect in these genes is also found in other cholestatic diseases such as intrahepatic cholestasis of pregnancy (ICP) and drug-induced cholestasis (DIC) (5-7).

BRIC is characterized by episodes of cholestasis that last from weeks to years followed by complete resolution in between $(8,9)$. Clinical manifestations of BRIC are mostly related to the liver. These include jaundice, anorexia, pruritus, vomiting, steatorrhea, malabsorption, vitamin $\mathrm{K}$ deficiency and weight loss $(10,11)$. Nonetheless, other extrahepatic manifestations have been reported, such as hearing loss, acute pancreatitis, and diarrhea in ATP8B1 mutations and formation of gallstones in ABCB11 defects $(4,10,12)$. BRIC is associated with a good prognosis and does not usually lead to fibrosis, in opposition to PFIC which is characterized by continuous cholestasis leading to liver fibrosis $(2,13)$. Nevertheless, progression from BRIC to PFIC has been described, reflecting the possible nature of both diseases as being part of the same spectrum $(14,15)$. The pathophysiology and triggers of BRIC have not been studied yet. Most reported episodes of BRIC were not associated with specific trigger factor and thus considered idiopathic. However, in many other cases, it was associated with preceding events such as upper respiratory infections, viral infections, pregnancy, oral contraceptive pills (OCPs) and others (9). Also, other reports suggested a seasonal pattern of BRIC $(9,16,17)$.

Basic understanding of BRIC's pathophysiology started with the observation of an intrinsic defect in bile salts (BS) transportation, followed by mapping FIC1 and $\mathrm{ABCB} 11$ genes that are responsible for BRIC 1 and 2 respectively $(2,18)$. However, not much is known about the episodic nature of this disease, nor about the role of certain factors in inducing it and the mechanisms behind them. Previous reviews on PFIC and BRIC were mainly narrative and did not focus on trigger factors (19). To elaborate the triggers and pathophysiology of BRIC, we conducted a review of case reports that include BRIC cases with an associated trigger using a methodological demarche. Additionally, we reviewed the possible mechanism by which potential factors trigger BRIC.

\section{Methods}

We conducted a search for articles published till October 2020 via PubMed searching engine using

\footnotetext{
Correspondence to : Ahmad Halawi, Faculty of Medical Sciences, Lebanese University, Beirut, Lebanon. Phone: +96171930909 E-mail: Halawiahmad.lb@gmail.com

Submission date : 08/02/2021

Acceptance date : 15/03/2021
} 


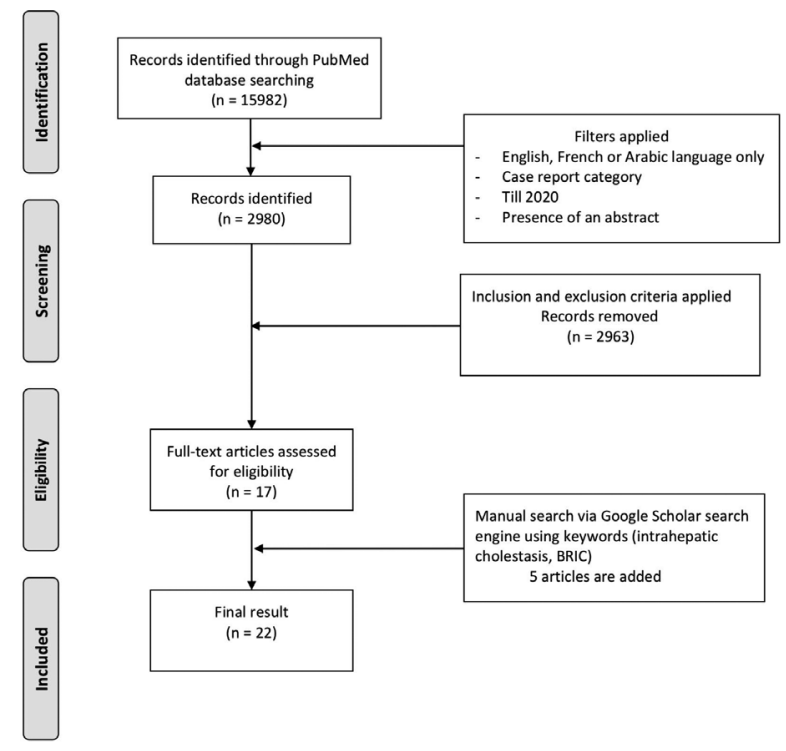

Figure 1. - Flow diagram of the literature review

the key words: "cholestasis, intrahepatic", "Benign recurrent intrahepatic cholestasis" and "Summerskill's syndrome" (figure 1). We reviewed and analyzed the identified papers based on the relevance to the topic. The search was limited to case report categories in English, French or Arabic language, which included an abstract. We ended up with 2980 articles. Publications that did not describe a clear presentation of BRIC (example : focusing on treatment without a detailed case presentation) or presented an overlapping presentation between BRIC and PFIC were excluded. Furthermore, papers meeting the above criteria were analyzed and only articles presenting a clear potential trigger were included. At this point, total number of articles meeting the above criteria was 17 . In addition, we performed a manual search via Google Scholar search engine for relevant case reports meeting our criteria. We had a total result of 22 articles describing 35 patients diagnosed with BRIC, who had at least one episode that was associated with a potential trigger (figure 1). For each case (patient), data related to gender, age at presentation, age at first episode, number of episodes, triggers, season, related genetic defects, duration of the longest episode, and family history were extracted. Trigger factors were classified into 4 categories: A- hormones: regrouping pregnancy and OCPs; B- infection : including different types of viral and bacterial infections; C- drugs; D- miscellaneous.

\section{Results}

Tables 1, 2, and 3 summarize all the cases found to have an associated trigger. 22 articles reported 35 different patients labeled from 1 to 35 . Of all cases, 22 were females $(62.9 \%)$. The mean number of episodes was $5.31 \pm 3.42$. The duration of the longest episode ranged from 3 months to 2 years with a mean of 32.37 weeks. The mean age at first episode was 14.28 years ranging from 3 months to 48 years. Meanwhile, the mean age at presentation was $31.47 \pm 16.82$ year (table 4 ).

Of all 35 patients, 6 had a defect in bile salt export pump (BSEP) and a similar number had a defect in ATP8B1. Extrahepatic complications were distributed between gallstones and pancreatitis revealing 7 patients having gallstones compared to 4 having pancreatitis. Family history was reported in 15 patients while others did not have a family history or data were unavailable. 11 episodes happened in winter season and 6 in autumn compared to 5 and 4 episodes that happened in spring and summer respectively.

Of all 170 episodes of BRIC, 70 (41.1\%) were associated with an identified trigger factor. Overall, infection was the most commonly reported trigger $(54.3 \%)$ followed by hormones $(30 \%)$, drugs $(10 \%)$, and miscellaneous (5.7\%). Pregnancy was reported in 16 episodes with 12 that occurred during the first 2 trimesters compared to 1 in the third and 3 unspecified. OCPs were found in 5 episodes. Of all infectious causes, viral infection such as upper respiratory tract infection (URTI), simple viral illness, and influenza were reported in 22 occasions. Bacterial infections such as tonsillitis, skin infection, otitis media, pneumonia and urinary tract infection (UTI) were reported in 13 episodes. Few drugs were reported such as: tetracycline, acetaminophen, amoxicillin-clavulanic acid, cefuroxime, erythromycin, and sulfonamides. Other causes such as vaccines and hyperthyroidism were reported on an individual basis. The trigger factors are summarized in table 5 .

\section{Discussion}

Basic understanding of the pathophysiology of intrahepatic cholestasis in BRIC was primarily based on two hypotheses: the first one attributes BRIC to an intrinsic defect in bile salts elimination, while the second attributes it to circulating substances that induce cholestasis $(17,18,38)$. Studies of van Berge et al, and later those of Summerfield et al, on serum bile acids (BA) in a patient with BRIC during a cholestatic attack demonstrated an elevation in BA, in addition to a discrepancy between BA and bilirubin. This elevation of BA early in the course followed by a rise in bilirubin was the initial evidence for the role of BA elimination in this disease $(17,18)$. An experiment conducted by Minuk et al, which consisted of transfusing the serum of a patient with BRIC into rats, did not result in any cholestatic finding in these rats; this was also in favor of the intrinsic defect hypothesis (38). Later on, a defect on the chromosome 18q21-22 was detected in patients with BRIC and was referred to us as FIC1 gene $(2,39,40)$. Then, during the last decade, ABCB11 gene (BSEP transporter) was mapped and attributed to BRIC $2(4,41)$.

Briefly, current knowledge on the pathophysiology of BRIC reveals that a defect in BSEP or in ATP8B1 results in an impairment of BS elimination and accumulation, subsequently leading to cholestasis $(5,42)$. BS retention is 
Table 1. - Summary of BRIC case reports reporting at least one potential trigger factor from 1959-1988

\begin{tabular}{|c|c|c|c|c|c|c|c|c|c|c|c|c|}
\hline Case & Reference & Year & Sex & Age (y) & $\begin{array}{l}\text { Age at } 1^{\text {st }} \\
\text { episode }\end{array}$ & $\begin{array}{c}\mathrm{nb} \text { of } \\
\text { episodes }\end{array}$ & Trigger factor & $\begin{array}{l}\text { Genetic } \\
\text { Defect }\end{array}$ & $\begin{array}{l}\text { Extrahepatic } \\
\text { complication }\end{array}$ & $\begin{array}{l}\mathrm{Nb} \text { of attack } \\
\text { per month }\end{array}$ & $\begin{array}{l}\text { Longest } \\
\text { episode }\end{array}$ & $\begin{array}{c}\text { FH of } \\
\text { cholestasis }\end{array}$ \\
\hline 1 & $\begin{array}{l}\text { Summerskill and } \\
\text { Walshe [1] }\end{array}$ & 1959 & $\mathrm{~F}$ & 29 & $9 y$ & 5 & $\begin{array}{l}\text { pregnancy }(a) x 1 \\
\text { influenza x1 }\end{array}$ & NA & NA & $\begin{array}{l}\text { Mar x1 } \\
\text { Oct x1 } \\
\text { Sep x2 } \\
\end{array}$ & $2 \mathrm{y}$ & NA \\
\hline 2 & Stark [20] & 1967 & $\mathrm{~F}$ & NA & $17 \mathrm{~m}$ & 9 & Otitis media $\times 2$ & NA & NA & NA & $6 \mathrm{~m}$ & NA \\
\hline 3 & Lesser [21] & 1973 & $\mathrm{~F}$ & 23 & $20 \mathrm{y}$ & 2 & OCPs / tetracycline & NA & NA & Oct $\mathrm{x} 1$ & $7 \mathrm{w}$ & Brother \\
\hline 4 & Lesser & 1973 & $\mathrm{~F}$ & 46 & $21 \mathrm{y}$ & 13 & $\begin{array}{c}\text { Pregnancy x } 5 \\
\text { Viral illness x } 1 \\
\text { OCPs x } 2 \\
\text { Flu vaccine } x 1\end{array}$ & NA & NA & NA & $7 \mathrm{~m}$ & Sister \\
\hline 5 & De pagter et al [22] & 1976 & $\mathrm{~F}$ & 11 & $1 \mathrm{y}$ & NA & Viral illness $\mathrm{x}$ ? & NA & NA & NA & $3 w$ & Sister \\
\hline 6 & De pagter et al & 1976 & $\mathrm{~F}$ & 53 & $14 \mathrm{~d}$ & $<8$ & Pregnancy x1 & NA & Gallstones & NA & $2 \mathrm{y}$ & $\begin{array}{c}\text { Father's } \\
\text { family }\end{array}$ \\
\hline 7 & De pagter et al & 1976 & M & 41 & $6 \mathrm{y}$ & $<3$ & Tonsillitis $\mathrm{x} 1$ & NA & NA & NA & NA & Sister \\
\hline 8 & $\begin{array}{l}\text { Summerfield et } \\
\text { al [17] }\end{array}$ & 1980 & M & 51 & $18 \mathrm{y}$ & 11 & Viral illness $\mathrm{x}$ ? & NA & Gallstones & NA & $3 \mathrm{~m}$ & NA \\
\hline 9 & Summerfield et al & 1980 & M & 66 & $28 \mathrm{y}$ & 5 & $\begin{array}{c}\text { URTI x2 } \\
\text { (UTI x1 and } \\
\text { Sulfonamides) }\end{array}$ & NA & Gallstones & NA & $3 \mathrm{~m}$ & NA \\
\hline 10 & Cohen et al [23] & 1985 & $\mathrm{~F}$ & 58 & $48 \mathrm{y}$ & 4 & Tonsillitis $\mathrm{x} 2$ & NA & NA & NA & $4 \mathrm{~m}$ & NA \\
\hline
\end{tabular}

Pregnancy(a): during first 2 trimesters NA: data not available; F: female; M: male; y: year; d: day; w: week; m: month; URTI: upper respiratory tract infection; UTI: urinary tract infection; OCPs: oral contraceptive pills; x: number of times; Nb: number; FH: family history; ?: unknown; Mar: March; Oc t: October; Sep: September.

Table 2. - Summary of BRIC case reports reporting at least one potential trigger factor from 1989-2011

\begin{tabular}{|c|c|c|c|c|c|c|c|c|c|c|c|c|}
\hline Case & Reference & Year & Sex & Age (y) & $\begin{array}{l}\text { Age at } 1^{\text {st }} \\
\text { episode }\end{array}$ & $\begin{array}{c}\mathrm{Nb} \text { of } \\
\text { episodes }\end{array}$ & Trigger factor & $\begin{array}{l}\text { Genetic } \\
\text { Defect }\end{array}$ & $\begin{array}{l}\text { Extrahepatic } \\
\text { complication }\end{array}$ & $\begin{array}{l}\mathrm{Nb} \text { of attack } \\
\text { per month }\end{array}$ & $\begin{array}{l}\text { longest } \\
\text { episode }\end{array}$ & $\begin{array}{c}\text { FH of } \\
\text { cholestasis }\end{array}$ \\
\hline 11 & Lau et al [24] & 1989 & $\mathrm{~F}$ & 15 & $11 \mathrm{y}$ & 5 & Influenza x2 & NA & NA & Aug x1 & $6 \mathrm{~m}$ & Brother \\
\hline 12 & Bijleveld et al [16] & 1989 & M & 7 & $1 \mathrm{y}$ & 2 & Gastroenteritis $\mathrm{x} 1$ & NA & NA & NA & $6 \mathrm{~m}$ & Brother \\
\hline 13 & Brenard et al [25] & 1989 & $\mathrm{~F}$ & 25 & NA & 2 & Pregnancy(a) x1 & NA & NA & NA & $7 \mathrm{~m}$ & NA \\
\hline 14 & Brenard et al & 1989 & $\mathrm{~F}$ & 46 & NA & 7 & Pregnancy (a) x1 & NA & NA & NA & $4 \mathrm{~m}$ & Sister \\
\hline 15 & Brenard et al & 1989 & $\mathrm{~F}$ & 30 & NA & 3 & Pregnancy (b) x1 & NA & Gallstones & NA & $4 \mathrm{~m}$ & NA \\
\hline 16 & Brenard et al & 1989 & $\mathrm{~F}$ & 37 & NA & 8 & Pregnancy (a) x1 & NA & Gallstones & NA & $15 \mathrm{~m}$ & NA \\
\hline 17 & Brenard et al & 1989 & $\mathrm{~F}$ & 23 & NA & 3 & Pregnancy (a) x1 & NA & NA & NA & $12 \mathrm{~m}$ & Brother \\
\hline 18 & Brenard et al & 1989 & $\mathrm{~F}$ & 48 & NA & 2 & Pregnancy(a) x1 & NA & NA & NA & $2 \mathrm{~m}$ & NA \\
\hline 19 & Bijleveld et al & 1989 & $\mathrm{M}$ & 14 & $8 \mathrm{y}$ & 9 & Gastroenteritis $\mathrm{x} 1$ & NA & NA & $\begin{array}{c}\text { Nov x2/Dec } \\
\mathrm{x} 2 / \text { Jan } x 4 / \\
\text { Feb x } 1\end{array}$ & $6 \mathrm{~m}$ & Brother \\
\hline 20 & Lovisetto et al [26] & 1990 & $\mathrm{~F}$ & 42 & $5 \mathrm{y}$ & 10 & Pregnancy (a) x1 & NA & Gallstones & NA & NA & Brother \\
\hline 21 & Al drees et al [27] & 1999 & $\mathrm{~F}$ & 11 & $4 \mathrm{y}$ & 3 & Viral illness x1 & NA & NA & NA & $8 \mathrm{w}$ & NA \\
\hline 22 & Kubitz et al [28] & 2006 & M & 17 & $3 \mathrm{~m}$ & 5 & $\begin{array}{c}\text { URTI x1 } \\
\text { Viral illness x3 }\end{array}$ & BSEP & NA & NA & $8 \mathrm{w}$ & NA \\
\hline 23 & Ermis et al [29] & 2010 & M & 23 & $11 \mathrm{y}$ & 3 & URTI x1 & ATP8B1 & NA & NA & $6 \mathrm{w}$ & NA \\
\hline 24 & Beausejour et al [30] & 2011 & $\mathrm{~F}$ & NA & NA & $2-3$ & $\begin{array}{l}\text { URTI } \mathrm{x} ? \\
\text { OCPs } \mathrm{x} ?\end{array}$ & BSEP & Pancreatitis $\mathrm{x} 1$ & NA & $18 \mathrm{~m}$ & Sister \\
\hline 25 & Beausejour et al [30] & 2011 & $\mathrm{~F}$ & NA & $9 \mathrm{~m}$ & $2-3$ & $\begin{array}{l}\text { URTI } x ? \\
\text { OCPs } x ?\end{array}$ & BSEP & NA & NA & $1.5 \mathrm{y}$ & Sister \\
\hline
\end{tabular}

Pregnancy (a): during first 2 trimesters; Pregnancy (b): during third trimester. NA: data not available; F: female; M: male; y: year; w: week; m: month; URTI: upper respiratory tract infection; OCPs: oral contraceptive pills; x: number of times; Nb: number; FH: family history; ?: unknown; Aug: August; Feb: February; Jan: January; Dec: December; Nov: November.

considered toxic and could lead to liver injury by activation of deteriorative response. This can lead to mitochondrial impairment, oxidative stress, inflammation, and cell death that result in a viscous cycle of BS retention and cell destruction (43-45). The mechanism initiating this cascade of BS retention is still unknown and thought to be idiopathic; however, as described above it could be triggered. In the upcoming sections, we highlight the possible mechanisms by which triggers - found in our review - induce BS retention. Evaluating how each single trigger could lead to cholestasis is not possible due to the rarity of the association and lack of studies on BRIC patients. For that reason, we regrouped reported trigger factors under four categories (table 5) : A- hormone; Binfection; C- medication; D- miscellaneous.

\section{Hepatocyte transport system}

In order to facilitate the understanding of the possible mechanism of BRIC induction, we refer to the hepatocellular transport system in figure (2). The transport of substances across hepatocytes are mainly 
Table 3. - Summary of BRIC case reports reporting at least one potential trigger factor from 2012-2020

\begin{tabular}{|c|c|c|c|c|c|c|c|c|c|c|c|c|}
\hline Case & Reference & Year & Sex & Age (y) & $\begin{array}{l}\text { Age at } 1^{\text {st }} \\
\text { episode }\end{array}$ & $\begin{array}{c}\mathrm{Nb} \text { of } \\
\text { episodes }\end{array}$ & Trigger factor & $\begin{array}{l}\text { Genetic } \\
\text { Defect }\end{array}$ & $\begin{array}{l}\text { Extrahepatic } \\
\text { complication }\end{array}$ & $\begin{array}{l}\mathrm{Nb} \text { of attack } \\
\text { per month }\end{array}$ & $\begin{array}{l}\text { longest } \\
\text { episode }\end{array}$ & $\begin{array}{c}\text { FH of } \\
\text { cholestasis }\end{array}$ \\
\hline 26. & Folvik et al [10] & 2012 & $\mathrm{M}$ & 42 & $27 \mathrm{y}$ & 10 & URTI x 5 & ATP8B1 & Pancreatitis $\mathrm{x} 2$ & Jan x1 & $12 \mathrm{w}$ & Twin \\
\hline 27. & Folvik et al & 2012 & $\mathrm{M}$ & 62 & $41 \mathrm{y}$ & 12 & $\begin{array}{l}\text { Pneumonia x1 vs } \\
\text { erythromycin }\end{array}$ & NA & NA & NA & $8 \mathrm{~m}$ & NA \\
\hline 28. & Folvik et al & 2012 & M & 21 & $15 \mathrm{y}$ & 7 & Havrix x2 & ATP8B1 & Pancreatitis x2 & $\begin{array}{c}\text { Decx1/ June } \\
\text { x1/ July x1 } \\
\text { /April x1/ } \\
\text { Sept x1 May } \\
\text { x1 /March x1 }\end{array}$ & $14 \mathrm{w}$ & NA \\
\hline 29. & Mizuochi et al [31] & 2012 & $\mathrm{~F}$ & 7 & $7 y$ & 1 & Influenza x1 & ATP8B1 & NA & NA & $2 y$ & NA \\
\hline 30. & $\begin{array}{l}\text { Moghadamrad et } \\
\text { al [32] }\end{array}$ & 2013 & $\mathrm{~F}$ & 44 & $44 \mathrm{y}$ & 1 & $\begin{array}{l}\text { Gastroenteritis x1 } \\
\text { vs acetaminophen }\end{array}$ & BSEP & gallstones & NA & NA & $\begin{array}{c}\text { Grand } \\
\text { mother and } \\
\text { aunt } \\
\end{array}$ \\
\hline 31. & Urszula et al [33] & 2014 & M & 14 & $14 \mathrm{y}$ & 3 & $\begin{array}{l}\text { Tetracycline vs skin } \\
\text { infection } \mathrm{x} 1\end{array}$ & ATP8B1 & NA & NA & $3 \mathrm{~m}$ & NA \\
\hline 32. & Schreiner et al [34] & 2019 & $\mathrm{M}$ & 16 & $16 \mathrm{y}$ & 3 & $\begin{array}{c}\text { Tonsillitis x2 } \\
\text { vs cefuroxime/ } \\
\text { amoxicillin- } \\
\text { clavulanic acid }\end{array}$ & BSEP & NA & NA & NA & NA \\
\hline 33. & Halawi et al [35] & 2020 & $\mathrm{~F}$ & 37 & $3 \mathrm{~m}$ & 8 & $\begin{array}{c}\text { Pregnancy } \mathrm{x} 1 \\
\text { Pneumonia x1 } \\
\text { Hyperthyroidism x1 }\end{array}$ & ATP8B1 & Pancreatitis $\mathrm{x} 1$ & Feb x1 & $5 \mathrm{~m}$ & NA \\
\hline 34. & Arthur et al [36] & 2020 & $\mathrm{~F}$ & 27 & $24 \mathrm{y}$ & 3 & Pregnancy x1 & BSEP & NA & NA & NA & NA \\
\hline 35. & Salyani et al [37] & 2020 & M & 21 & $14 \mathrm{y}$ & 6 & Skin infection $\mathrm{x} 2$ & NA & NA & $\begin{array}{c}\text { Dec x1 } \\
\text { April x1 } \\
\text { June x2 }\end{array}$ & $8 \mathrm{w}$ & NA \\
\hline
\end{tabular}

NA: data not available; F: female; M: male; y: year; w: week; m: month; URTI: upper respiratory tract infection; OCPs: oral contraceptive pills; x: number of times; Nb: number; FH: family history; ?: unknown; Dec: December; Apr: April; Feb: February; Sept: September.

Table 4. - Summary of variables presented in table 1-3

\begin{tabular}{|c|c|c|c|c|c|c|c|c|}
\hline Sex & $\begin{array}{l}\text { Mean number of } \\
\text { episodes (SD) }\end{array}$ & $\begin{array}{c}\text { Mean age at } \\
\text { presentation }(\mathrm{SD})\end{array}$ & Genetic defect & $\begin{array}{l}\text { Extrahepatic } \\
\text { complication }\end{array}$ & $\begin{array}{l}\text { Mean age at first } \\
\text { episode(range) }\end{array}$ & Season & $\begin{array}{l}\text { Mean Duration } \\
\text { of longest } \\
\text { episode (range) }\end{array}$ & $\begin{array}{l}\text { Presence of } \\
\text { family history }\end{array}$ \\
\hline $\begin{array}{l}\mathrm{F}: 62.9 \% \\
\mathrm{M}: 37.1 \%\end{array}$ & $5.31 \pm 3.42$ & $31.47 \pm 16.82$ & $\begin{array}{c}\text { BSEP: } 6 \mathrm{x} \\
\text { ATP8B1:6x }\end{array}$ & $\begin{array}{l}\text { Pancreatitis:6x } \\
\text { Gallstones:6x }\end{array}$ & $14.28(3 \mathrm{~m}-48 \mathrm{y})$ & $\begin{array}{l}\text { Winter: } 11 \mathrm{x} \\
\text { Autumn:6x } \\
\text { Spring:5x } \\
\text { Summer:4x }\end{array}$ & $32.37 \%(3 \mathrm{~m}-2 \mathrm{y})$ & $42.8 \%$ \\
\hline
\end{tabular}

F: female; M: male; SD: standard deviation; $x$ : number of time; m: month; y: year.

assured by two groups of transporters, depending on their locations in the polarized hepatocytes : canalicular or basolateral (sinusoidal) transporter (46). While the former is responsible for the direct passage of substances into the bile tract, the latter assures the communication between sinusoidal blood and hepatocytes (46).

Briefly, organic compounds, that are mainly bound to albumin, pass through the endothelial fenestrae of the liver sinusoids into the space of Disses, then into the hepatocytes via the basolateral transport system (47). This system is further divided into $\mathrm{Na}^{+}$-dependent and $\mathrm{Na}^{+}$-independent transporters (48). Of these transporters, we have : Na-taurocholate co-transporting polypeptides (NTCPs) which are glycoproteins mainly responsible for BS uptake by hepatocytes (49); organic anion binding polypeptides (OATPs) that are in charge of non-BS organic anions uptake such as bilirubin, leukotrienes, thyroid hormones, estrogen and xenobiotics (50); multi-drug resistance associated proteins (MRPs) which are ATP-dependent pumps mainly involved in the compensation of cholestatic conditions, assisting in the elimination of BS (51); organic cation transporter (OCTs) which mediate hepatocellular uptake of organic cations of endogenous (e.g., dopamine) or exogenous (e.g., drugs like procainamide) origin (52). Finally, there is aquaporin-9 (AQP9), a water selective channel located in hepatocytes (53).

The second group of transporters constitutes the canalicular system responsible for BS transfer from blood to bile $(54,55)$. As part of this system, we have : multidrug resistance-1 (MDR1) that functions as an efflux protein for many endogenous and exogenous substances such as toxins, steroids, metabolites, and others. Hence, it is implicated in drug resistance in hepatocellular carcinomas $(56,57)$; There is also multi-drug resistance-3 (MDR3), a flippase that is responsible for translocating phosphatidylcholine (PC) from the inner leaflet to the outer one of the canalicular membrane, leading to a release of $\mathrm{PC}$ vesicles into bile (58). Aquaporin 8 (AQP8) plays a role in bile formation by altering the osmotic movement (59). The MRP family is also active in the canalicular part, especially via MRP2 (multi-drug 
A

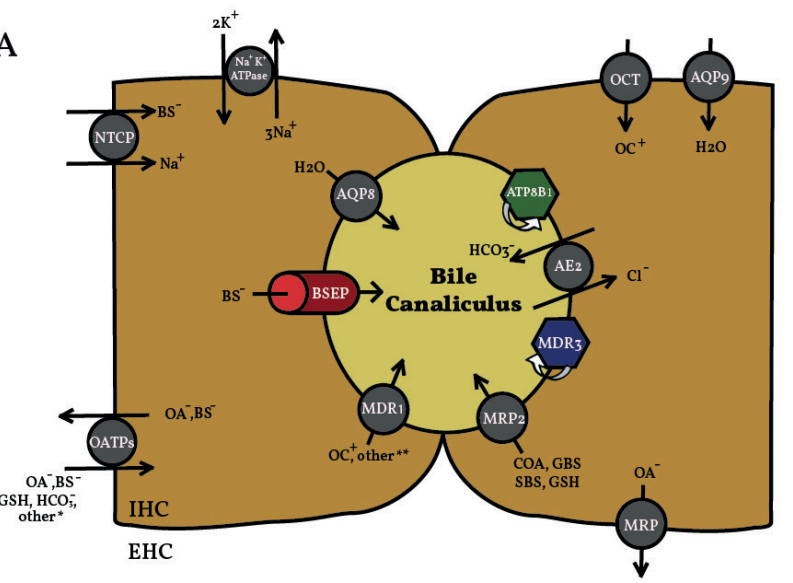

B
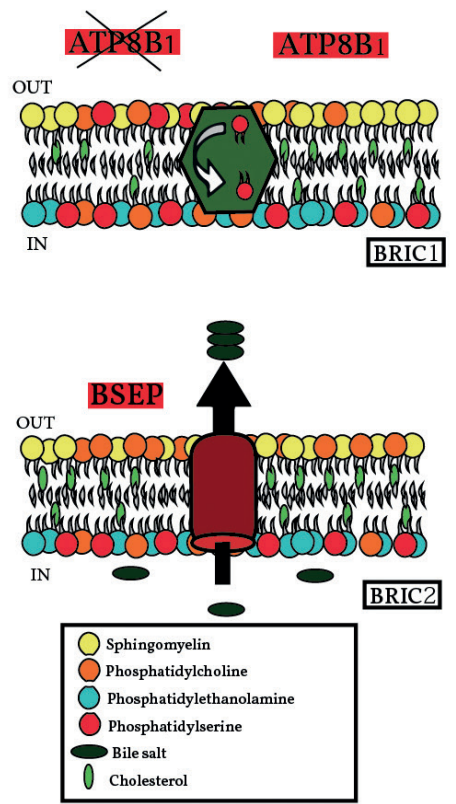

Figure 2. - (A) Hepatocellular transport system representing both basolateral and canalicular systems ; IHC : intrahepatic component ; EHC : extrahepatic component; ATP8B1 : ATPase phospholipid transporting 8B1; AE2 : Anion exchange protein 2; AQP8/9 : Aquaporin 8/9 ; BS : bile salts ; BSEP : Bile salt export pump ; OA : Organic anions ; OC : Organic cations ; MDR3 : Multidrug resistance protein3 ; MRP : Multidrug resistance associated protein ; OATPs : Organic anion transporting polypeptides ; NTCP : Sodium-taurocholate cotransporting polypeptide ; MRP2 : Multidrug resistance associated 2; OCT : Organic cations transporter ; HCO3 : Bicarbonate ; GSH : Glutathione; COA : Conjugated organic anions; SBS : Sulfated-bile salts ; GBS : Glucuronide-Bile salts ; * : leukotrienes, thyroid hormones, estrogen, and xenobiotics ; ** : toxinsand steroids. (B) Role of ATP8B1 as a flippase that mediates the translocation of phospatidylserine (in red) from the outer leaflet to the inner one of the plasma membrane. Thus, it conserves the asymmetry and fluidity of the membrane. The main function of BSEP is to export bile salts especially monovalent into the bile canals ; IN : intracellular side ; OUT : bile canaliculus side ; BRIC : benign recurrent intrahepatic cholestasis.

Table 5. - Summary of BRIC trigger factors

\begin{tabular}{|l|c|c|}
\hline Triggers & Episodes & Percentage \\
\hline INFECTION & 38 & $54.29 \%$ \\
\hline Upper respiratory tract infection & 10 & $14.3 \%$ \\
\hline Viral illness & 8 & $11.4 \%$ \\
\hline Tonsillitis & 5 & $7.1 \%$ \\
\hline Influenza & 4 & $5.7 \%$ \\
\hline Gastroenteritis & 3 & $4.3 \%$ \\
\hline Skin infection & 3 & $4.3 \%$ \\
\hline Otitis media & 2 & $2.9 \%$ \\
\hline Pneumonia & 2 & $2.9 \%$ \\
\hline Urinary tract infection & 1 & $1.4 \%$ \\
\hline HORMONES & 21 & $30 \%$ \\
\hline Pregnancy & 16 & $22.9 \%$ \\
\hline Oral contraceptive pills & 5 & $7.1 \%$ \\
\hline DRUGS & 7 & $10 \%$ \\
\hline Tetracycline & 2 & $2.9 \%$ \\
\hline Acetaminophen & 1 & $1.4 \%$ \\
\hline Amoxicillin-clavulanic acid & 1 & $1.4 \%$ \\
\hline Cefuroxime & 1 & $1.4 \%$ \\
\hline Erythromycin & 1 & $1.4 \%$ \\
\hline Sulphonamides & 1 & $1.4 \%$ \\
\hline MISCELLANEAOUS & 4 & $5.71 \%$ \\
\hline Havrix & 1 & $2.9 \%$ \\
\hline Flu vaccine & & $1.4 \%$ \\
\hline Hyperthyroidism & 1 & \\
\hline & & \\
\hline & 1 & \\
\hline
\end{tabular}

resistance-2), which is associated with Dubin-Johnson syndrome (60). It facilitates the secretion of different organic anions in the bile system such as : glutathione S-conjugate, leukotriene C4, 17beta-glucuronosyl estradiol, glucuronosyl bilirubin, glutathione disulfide $(61,62)$. Anion exchange protein 2 (AE2), as part of $\mathrm{Na}^{+}$-independent anion exchangers, is responsible for Cl$\mathrm{HCO} 3$ - exchange, hence preserving the electroneutrality (63). The major canalicular transporters that are involved in BRIC disease are BSEP and ATP8B1, which is part of P4 ATPases family (64). BSEP is known as a sister of P-glycoprotein (SPGP) due to its homology with MDR (multi-drug resistant) glycoprotein (65). It was found to be the major protein defected in BRIC type 2, in addition to other cholestatic diseases such as : PFIC 2, DIC, and ICP (66). BSEP is encoded by ABCB11 gene that is found on chromosome $2 \mathrm{q} 24$. The major role of BSEP, as its name implies, is to transport BS, especially monovalent conjugated ones, across canalicular membranes, and it constitutes the rate limiting step in the passage of BS from hepatocytes to bile canals (67). The regulation of BSEP, as many canalicular channels, usually happens on three major levels: transcriptional, post-transcriptional and post-translational (67). Transcriptional level implicates a primary role in transactivation pathways, especially bile 
acid receptor/farnesoid $X$ receptor (BAR/FXR) signaling pathway where BS induce mRNA expression of BSEP (67). In fact, many substances such as estrogen were found to alter these pathways, resulting in alteration in BSEP function and/or expression, as we will discuss later. FIC1 gene encodes a canalicular protein, the ATP8B1. This protein is a flippase that mediates the translocation of aminophospholipids (phospatidylserine) from the outer leaflet to the inner one of the plasma membrane $(68,69)$. Thus, it conserves the asymmetry and fluidity of the membrane. A recent function of ATP8B1 was related to its implication in microvillus formation in polarized epithelial cells (70). In addition, the absence of ATP8B1 in the intestinal Caco-2 cells was found to impair the BS uptake via NTCP2 in these cells which may be implicated in the pathophysiology of diarrhea in patients with ATP8B1 deficiency (71).

\section{Hormonal}

This category encompasses pregnancy and OCPs. Based on our findings, pregnancy was reported in several cases $(22.9 \%)$ as a potential trigger for BRIC, mainly during the first two trimesters. This feature is of extreme importance, since the other benign cholestatic disease related to pregnancy, ICP, presents with cholestasis mainly in the third trimester of pregnancy $(6,72,73)$. Indeed, BRIC and ICP can present with a similar clinical course, especially if patients have their first attack of BRIC during pregnancy, which was the case with patient number 34 (Table 3) (36). OCPs were associated with BRIC in $7.1 \%$ of cases. OCPs are known to cause cholestasis regardless of BRIC, which make them a good candidate for BRIC induction (74). As opposed to pregnancy, a relation between OCPs and BRIC is more difficult to assess and can be questioned. In most reported cases, a chronological relation between starting or stopping OCPs and cholestatic episodes is not clear. Brenard et al, in his case series of 26 BRIC cases, found that the discontinuation of OCPs in patients having BRIC attack did not lead to any obvious improvement, making the causality relation weaker (25).

In general, the effect of OCPs and pregnancy on inducing cholestasis is mainly related to the estrogenic component as demonstrated in $\operatorname{ICP}(68,75-77)$. As a result, a possible hypothesis to understand the mechanism by which pregnancy and OCPs induce cholestasis in BRIC patients is by elaborating the action of estrogens and their metabolites on hepatic transporters, especially ATP8B1 and BSEP in rodents. In a normal state, the physiological response to the increase in BS leads to an increase in the expression of BSEP as a regulatory mechanism, and thus an increase in the elimination of excess BS (67). This compensatory mechanism is primarily mediated by transactivation pathways, especially BS/FXR signaling pathway (78-80). In that sense, an increase in BS stimulates FXR and prevents BS accumulation (81,82). Nevertheless, in high estrogenic state, the function and expression of BSEP decrease notably $(76,81)$. BS/FXR signaling pathway in addition to estrogen receptor/ estrogen receptor alpha (ER/ER-a) form the major cause of decrease in BSEP expression in response to high estradiol (E2) level $(76,81)$. Song et al demonstrated that E2 represses the expression of BSEP in late pregnancy via a non-classical E2/ER-a trans-repressive pathway that directly interacts with FXR after their observation on pregnant mice and human primary hepatocytes (76). These findings correlate with the course of ICP where cholestasis becomes apparent in the third trimester. However, the reason for which BRIC appears earlier in pregnancy is not clear. To investigate the mechanism behind the trans-repression of BSEP by E2 at the level of FXR, Chen et al demonstrated that E2 represses BSEP via a decrease in the recruitment of proliferator-activated receptor gamma co-activator1 (PGC-1) among other potential co-activators (81). Also, there is an increase in the recruitment of nuclear receptor corepressor (NCoR) among other corepressors to BSEP promotor in Huh7 human hepatoma cells (81). In addition, he demonstrated that this trans-repression is not ligand specific and different BS types can be involved (81).

Another way of BSEP alteration is mediated via endocytic internalization (83-86). This subcellular localization of transporters was seen in response to estradiol $17 \mathrm{~b}$ glucuronide (E217G) (84). While pre-vious studies have shown that estrogen induces Mrp2 internalization leading to cholestasis induction, many studies also recently demonstrated a possible similar action of estrogen on BSEP (87). Indeed, Crozenzi et al demonstrated in rats that $\mathrm{E} 217 \mathrm{G}$ leads to marked endocytic internalization of BSEP from membrane to intracellular vesicular-likestructure accompanied by impairment of BSEP transport activity (59). These findings were not observed in rats lacking Mrp2, reflecting an essential role for BSEP and Mrp2 in inducing cholestasis (59). To elicit the molecular mechanism of internalization in response to estrogen, Miszczuk et al found that the internalization of BSEP and Mrp2 in E217G induced cholestasis was accomplished using clathrin-mediated endocytosis in rats (88).

The fact that ATP8B1 and BSEP are defective in BRIC does not imply whether any trigger factor acts directly on these proteins. Other possible scenarios might relate to an interaction with other channels that is added to the initial defect, subsequently leading to cholestasis. Indeed, estrogen is also known to affect basolateral channels, and thus causing cholestasis (89-91). Estrogen primarily leads to the down regulation of all basolateral organic anion transporters by diminishing the nuclear binding activity of pregnane X receptor (PXR) (91). More possible implications of estrogen in inducing cholestasis are via the affection of hepatocytes polarity and disruption of tight junctions, leading to a backward diffusion of BS into sinusoidal space as well as an alteration in bile plasma osmotic gradient (92). This prominent role of estrogen in inducing cholestasis, does not eliminate a possible concomitant role for progesterone (93). 


\section{Drugs}

The association between drugs and BRIC seems to be the most challenging and complicated one due to the few number of cases and the absence of time and/ or dose relation in each episode. In addition, in most reported cases where a medication was assigned as a possible trigger factor, there were additional overlapping factors that could be the culprit. For example, in some cases, erythromycin was used to treat pneumonia, sulfa for urinary tract infection and tetracycline for skin infection $(10,17,33)$. In one reported case, a patient (27) had a BRIC attack following influenza A infection and the start of oseltamivir course; a negative drug-induced lymphocyte stimulation test using oseltamivir phosphate favored the possibility of influenza as being the trigger instead of oseltamivir (31).

In case of BRIC, ATP8B1 does not seem to have a role in drug-induced cholestasis since it is not a drug transporter. The defect in BSEP is the main contributory factor in its pathogenesis. Briefly, lipophilic drugs cross hepatocytes' cell membrane mainly via active or facilitated transport in the sinusoidal system (94). Then intracellularly, drugs undergo phase 1 and 2 metabolism leading to water soluble substances (95). Finally, the rate limiting step of this process constitutes its elimination via canalicular transporters, mainly BSEP and MRP2 in the bile (95). Drugs inducing cholestasis act on different levels : bile canaliculi dynamics, BS transporters, and cytoskeleton (96-98). The majority of drugs lead to competitive cis-inhibition of BSEP; other drugs also reduce its expression $(98,99)$. As for DIC, the most important reported variation in BSEP is V444A (100). Other canalicular transporters, such as MDR3, and basolateral canaliculi such as MRP3, MRP4, NRCP, and OATPs, are also implicated $(95,98,101,102)$.

\section{Infections}

Infection was reported in 38 occasions as a trigger event of BRIC (table 5). The majority of reported cases were related to a simple or mild viral infection, especially influenza virus and simple URTI. Less commonly, otitis media, skin infection, UTI, and gastroenteritis were reported. Pneumonia can be viewed from different perspectives. It is often reported as a possible complication of ATP8B1 mutation as seen in a patient with PFIC (13). Gastroenteritis was noted in patients from case reports (17) and (18) who had a simultaneous attack of BRIC after suffering from gastroenteritis (16). Gastroenteritis could alter the microflora which results in alteration in secondary bile salts, thus leading to diarrhea (103). Moreover, gastroenteritis is seen in prodromal phase or as an extrahepatic manifestation of BRIC $(4,71)$.

Reflections on the mechanism by which infection induce cholestasis come mainly from observations on rodents treated with lipopolysaccharides (LPS) and cytokines mimicking sepsis and inflammatory states
(73). In 1998, Crawford et al postulated that one form of hepatocellular cholestasis is inflammation-induced cholestasis, which is attributable to the inflammatory cytokine system activated by extrahepatic infections or inflammatory processes (104). However, evidence now reveals that through the activation of pro-inflammatory cytokines, inhibition of hepatobiliary transporter gene expression takes place; this leads to impaired transport and profound reduction of bile flow, resulting in hyperbilirubinemia and cholestasis (105).

LPS and endotoxins induce Kupffer cells to produce pro-inflammatory cytokines which cause a repressed activity of nuclear transcriptional factor, thus leading to a decrease in the expression of BSEP (106). LPS leads to the downregulation of both canalicular and basolateral transporters (107). Indeed, it showed that transcriptional downregulation of the export pumps BSEP and MRP2 accounts for the reduction in bile flow and secretion during endotoxinemia $(59,108)$. However, Jansen et al showed that following LPS treatment in animal models, rapid early retrieval of BSEP transporter takes place hours before the down-regulation of BSEP messenger ribonucleic acid (mRNA) and protein occurs (109). In a more recent experiment, Zollner and coworkers (2001) suggested a role for posttranscriptional and posttranslational mechanisms of BSEP regulation from percutaneous liver biopsy samples taken from patients with sepsis-induced cholestasis (110). By virtue of the latter, a more important role was attributed to posttranscriptional processes in humans. Since a mild infection, not resulting in sepsis, is a frequent trigger of BRIC, the inability to reproduce a similar model as in sepsis via LPS represents a major limitation in understanding its pathophysiology.

\section{Miscellaneous}

Vaccines were attributed to BRIC induction on few occasions. One interesting case is that of patient (26) (10). This patient with BRIC disease had a total of 7 attacks, with 2 of them occurring after taking hepatitis A inactivated vaccine "Havrix" (GlaxoSmithKline Biologicals). The mechanism underneath is not clear. Moreover, hyperthyroidism was associated with BRIC on one occasion (35). Thyroid dysfunction, especially hypothyroidism is a common cause of cholestasis but rarely leads to apparent jaundice (111). It is reported in patients with ATP81B1 deficiency as a possible extrahepatic manifestation of BRIC1 (112).

\section{Limitations}

The limitation of our study is mainly related to possible reporting and publication bias since data was extracted from case repots. In addition, the causality relationship was difficult to establish for many triggers due to the limited number of reports. Also, literature searching was primary done using one data base. 


\section{Conclusion}

In conclusion, BRIC is an episodic cholestatic disease that is associated with some trigger factors. Infections, with viral being more common than bacterial, and hormonal changes, resulting from pregnancy and OCPs use, are the main reported triggers. Other less significant triggers are drugs, vaccines, and hyperthyroidism. Knowing the trigger factors is a key element to prevent its occurrence, and identifying the pathophysiology of triggers such as pregnancy could facilitate a field for new therapeutic interventions. Therefore, high-quality clinical trials as well as molecular studies are needed to confirm the trigger factors and the underlying pathophysiology of such disease.

\section{Conflict of interest}

None declared.

\section{References}

1. SUMMERSKILL WH, WALSHE JM. Benign recurrent intrahepatic “obstructive" jaundice. Lancet 1959, 2 : 686-90. https://doi.org/10.1016/ s0140-6736(59)92128-2.

2. VAN BERGE HENEGOUWEN GP. Benign recurrent intrahepatic cholestasis and Byler's disease : one gene, two diseases? J. Hepatol. 1996, 25 : 395-7. https://doi.org/10.1016/S0168-8278(96)80128-0.

3. BAKER A, KERKAR N, TODOROVA L, KAMATH BM, HOUWEN RHJ. Systematic review of progressive familial intrahepatic cholestasis. Clin. Res. Hepatol. Gastroenterol. 2019, 43 : 20-36. https://doi.org/10.1016/j. clinre.2018.07.010

4. VAN MIL SWC, VAN DER WOERD WL, VAN DER BRUGGE G, STURM E, JANSEN PLM, BULL LN, et al. Benign recurrent intrahepatic cholestasis type 2 is caused by mutations in ABCB11. Gastroenterology 2004, 127 : 37984. https://doi.org/10.1053/j.gastro.2004.04.065

5. VAN DER WOERD WL, VAN MIL SWC, STAPELBROEK JM, KLOMP LWJ, VAN DE GRAAF SFJ, HOUWEN RHJ. Familial cholestasis: Progressive familial intrahepatic cholestasis, benign recurrent intrahepatic cholestasis and intrahepatic cholestasis of pregnancy. Best. Pract. Res. Clin. Gastroenterol. 2010, 24 : 541-53. https://doi.org/10.1016/j.bpg.2010.07.010.

6. DIXON PH, WILLIAMSON C. The pathophysiology of intrahepatic cholestasis of pregnancy. Clin. Res. Hepatol. Gastroenterol. 2016, 40 : 14153. https://doi.org/10.1016/j.clinre.2015.12.008.

7. DIETRICH CG, GEIER A. Effect of drug transporter pharmacogenetics on cholestasis. Expert Opin. Drug. Metab. Toxicol. 2014, 10 : 1533-51. https:// doi.org/10.1517/17425255.2014.963553.

8 LUKETIC VA, SHIFFMAN ML. Benign recurrent intrahepatic cholestasis. Clin. Liver Dis. 1999, 3: 509-28, viii. https://doi.org/10.1016/s10893261(05)70083-0.

9. LUKETIC VA, SHIFFMAN ML. Benign recurrent intrahepatic cholestasis. Clin. Liver Dis. 2004, 8: 133-49. https://doi.org/10.1016/S10893261(03)00133-8.

10. Folvik G, Hilde O, Helge GO. Benign recurrent intrahepatic cholestasis : review and long-term follow-up of five cases. Scand J Gastroenterol 2012, 47 : 482-8. https://doi.org/10.3109/00365521.2011.650191.

11. DE VLOO C, NEVENS F. Cholestatic pruritus: an update. Acta Gastroenterol.Belg. n.d., 82 : 75-82.

12. TYGSTRUP N, STEIG BA, JUIJN JA, BULL LN, HOUWEN RH. Recurrent familial intrahepatic cholestasis in the Faeroe Islands. Phenotypic heterogeneity but genetic homogeneity. Hepatology 1999, 29 : 506-8. https:// doi.org/10.1002/hep.510290214.

13. PAWLIKOWSKA L, STRAUTNIEKS S, JANKOWSKA I, CZUBKOWSKI $\mathrm{P}$, EMERICK K, ANTONIOU A, et al. Differences in presentation and progression between severe FIC1 and BSEP deficiencies. J. Hepatol. 2010, 53 : 170-8. https://doi.org/10.1016/j.jhep.2010.01.034.

14. VAN OOTEGHEM NA., KLOMP LW., VAN BERGE-HENEGOUWEN GP, HOUWEN RH. Benign recurrent intrahepatic cholestasis progressing to progressive familial intrahepatic cholestasis : low GGT cholestasis is a clinical continuum. J. Hepatol. 2002, 36 : 439-43. https://doi.org/10.1016/ S0168-8278(01)00299-9.

15. VAN MIL SW, KLOMP LW, BULL LN, HOUWEN RH. FIC1 Disease : A Spectrum of Intrahepatic Cholestatic Disorders. Semin. Liver Dis. 2001, 21 535-44. https://doi.org/10.1055/s-2001-19034.

16. BIJLEVELD CMA, VONK RJ, KUIPERS F, HAVINGA R, FERNANDES J. Benign recurrent intrahepatic cholestasis : A long-term follow-up study of two patients. Hepatology 1989, 9: 532-7. https://doi.org/10.1002/hep. 1840090404.

17. SUMMERFIELD JA, SCOTT J, BERMAN M, GHENT C, BLOOMER JR, BERK PD, et al. Benign recurrent intrahepatic cholestasis : studies of bilirubin kinetics, bile acids, and cholangiography. Gut 1980, 21 : 154-60. https://doi.org/10.1136/gut.21.2.154.

18. VAN BERGE HENEGOUWEN GP, BRANDT KH, DE PAGTER AG. Is an acute disturbance in hepatic transport of bile-acids the primary cause of cholestasis in benign recurrent intrahepatic cholestasis? Lancet 1974, 1 : 1249-51. https://doi.org/10.1016/s0140-6736(74)90004-x.

19. STRUBBE B, GEERTS A, VAN VLIERBERGHE H, COLLE I. Progressive familial intrahepatic cholestasis and benign recurrent intrahepatic cholestasis : a review. Acta Gastroenterol. Belg. 2012, 75 : 405-10.

20. STARK H. Benign recurrent cholestasis in a child. Pediatrics 1968, 41 : 6369.

21. LESSER PB. Benign familial recurrent intrahepatic cholestasis. Am. J. Dig. Dis. 1973, 18 : 259-64. https://doi.org/10.1007/bf01070985.

22. DE PAGTER AG, VAN BERGE HENEGOUWEN GP, TEN BOKKEL HUININK JA, BRANDT KH. Familial benign recurrent intrahepatic cholestasis. Interrelation with intrahepatic cholestasis of pregnancy and from oral contraceptives? Gastroenterology 1976, 71 : 202-7. https://doi. org/10.1016/S1089-3261(05)70083-0.

23. COHEN J, COHEN AL. Benign recurrent intrahepatic cholestasis (Summerskill and Walshe syndrome). Case report and revision of bibliography. Acta Gastroenterol. Latinoam. 1985, 15 : 113-21.

24. LAU JYN, LOK ASF, LAI CL, WU PC, LIN HJ. Benign recurrent intrahepatic cholestasis in a Chinese girl. J. Gastroenterol. Hepatol. 1989, 4 581-3. https://doi.org/10.1111/j.1440-1746.1989.tb00861.x.

25. BRENARD R, GEUBEL AP, BENHAMOU JP. Benign Recurrent Intrahepatic Cholestasis. J. Clin. Gastroenterol. 1989, 11 : 546-51. https:// doi.org/10.1097/00004836-198910000-00011.

26. LOVISETTO P, RAVIOLO P, RIZZETTO M, MARCHI L, ACTIS GC, VERME G. Benign recurrent intrahepatic cholestasis. A clinico-pathologic study. Ric. Clin. Lab. n.d., 20 : 19-27. https://doi.org/10.1007/BF02910145.

27. AL DREES K, AL ZABEN A, AL AMIR A, ABDULLA A. Benign recurrent intrahepatic cholestasis in a Saudi child. Ann. Trop. Paediatr. 1999, 19 : 215 7. https://doi.org/10.1080/02724939992563.

28. KUBITZ R, KEITEL V, SCHEURING S, KÖHRER K, HÖUSSINGER D Benign Recurrent Intrahepatic Cholestasis Associated With Mutations of the Bile Salt Export Pump. J. Clin. Gastroenterol. 2006, 40 : 171-5. https://doi. org/10.1097/01.mcg.0000196406.15110.60.

29. ERMIS F, ONCU K, OZEL M, YAZGAN Y, GURBUZ AK, DEMIRTURK $\mathrm{L}$, et al. Benign recurrent intrahepatic cholestasis : late initial diagnosis in adulthood. Ann. Hepatol. n.d., 9 : 207-10.

30. BEAUSÉJOUR Y, ALVAREZ F, BEAULIEU M, BILODEAU M. Description of Two New ABCB11 Mutations Responsible for Type 2 Benign Recurren Intrahepatic Cholestasis in a French-Canadian Family. Can. J. Gastroenterol. 2011, 25 : 311-4. https://doi.org/10.1155/2011/534918.

31. MIZUOCHI T, KIMURA A, TANAKA A, MUTO A, NITTONO H, SEKI $\mathrm{Y}$, et al. Characterization of urinary bile acids in a pediatric BRIC-1 patient : effect of rifampicin treatment. Clin. Chim. Acta 2012, 413 : 1301-4. https:// doi.org/10.1016/j.cca.2012.04.011.

32. MOGHADAMRAD S, MONTANI M, WEIMANN R, DE GOTTARDI A. Cholestasis in a patient with gallstones and a normal gamma-glutamyl transferase. Hepatology 2013, 57 : 2539-41. https://doi.org/10.1002/hep. 26344.

33. OŁDAKOWSKA-JEDYNAK U, JANKOWSKA I, HARTLEB M, JIRSA M, PAWŁOWSKA J, CZUBKOWSKI P, et al. Treatment of pruritus with Prometheus dialysis and absorption system in a patient with benign recurrent intrahepatic cholestasis. Hepatol. Re. 2014, 44 : E304-8. https://doi.org/10. 1111/hepr.12262

34. SCHREINER P, STIEGER B, MCLIN V, ROUGEMONT A-L, KEITEL V, DRÖGE C, et al. A rare cause of a cholestatic jaundice in a North African teenager. Liver Int. 2019, 39 : 2036-41. https://doi.org/10.1111/liv.14122.

35. HALAWI A, BITAR R, IBRAHIM N. Hyperthyroidism as a Potential Trigger for Benign Recurrent Intrahepatic Cholestasis. ACG Case Reports J. 2020, 7 : e00423. https://doi.org/10.14309/crj.0000000000000423.

36. ARTHUR LORIO E, VALADEZ D, ALKHOURI N, LOO N. Cholestasis in Benign Recurrent Intrahepatic Cholestasis 2. ACG Case Reports J. 2020, 7 e00412. https://doi.org/10.14309/crj.0000000000000412. 
37. SALYANI A, BARASA L, RAJULA A, ALI SK. Benign Recurrent Intrahepatic Cholestasis (BRIC): An African Case Report. Case Rep. Gastrointest. Med. 2020, 2020 : 1-5. https://doi.org/10.1155/2020/2894293.

38. MINUK GY, SHAFFER EA. Benign recurrent intrahepatic cholestasis. Evidence for an intrinsic abnormality in hepatocyte secretion. Gastroenterology 1987, 93 : 1187-93.

39. CARLTON VEH, KNISELY AS, FREIMER NB. Mapping of a locus for progressive familial intrahepatic cholestasis (Byler disease) to 18q21-q22, the benign recurrent intrahepatic cholestasis region. Hum. Mol. Genet. 1995, $4:$ : 1049-53. https://doi.org/10.1093/hmg/4.6.1049.

40. OUDE ELFERINK RPJ, VAN BERGE HENEGOUWEN GP. Cracking the genetic code for benign recurrent and progressive familial intrahepatic cholestasis. J. Hepatol. 1998, 29 : 317-20. https://doi.org/10.1016/S01688278(98)80020-2.

41. NOE J, KULLAK-UBLICK GA, JOCHUM W, STIEGER B, KERB R, HABERL M, et al. Impaired expression and function of the bile salt export pump due to three novel ABCB11 mutations in intrahepatic cholestasis. $J$ Hepatol. 2005, 43 : 536-43. https://doi.org/10.1016/j.jhep.2005.05.020.

42. STICOVAE, JIRSAM, PAWŁOWSKAJ. New Insights in Genetic Cholestasis : From Molecular Mechanisms to Clinical Implications. Can. J. Gastroenterol. Hepatol. 2018, 2018 : 1-12. https://doi.org/10.1155/2018/2313675.

43. YU T, WANG L, LEE H, O'BRIEN DK, BRONK SF, GORES GJ, et al Decreasing Mitochondrial Fission Prevents Cholestatic Liver Injury. J. Biol. Chem. 2014, 289 : 34074-88. https://doi.org/10.1074/jbc.M114.588616.

44. PEREZ MJ, BRIZ O. Bile-acid-induced cell injury and protection. World $J$. Gastroenterol. 2009, 15 : 1677. https://doi.org/10.3748/wjg.15.1677.

45. CAI S-Y, OUYANG X, CHEN Y, SOROKA CJ, WANG J, MENNONE A, et al. Bile acids initiate cholestatic liver injury by triggering a hepatocytespecific inflammatory response. JCI Insight 2017, 2. https://doi.org/10.1172/ jci.insight. 90780 .

46. BORLAK J, KLUTCKA T. Expression of basolateral and canalicular transporters in rat liver and cultures of primary hepatocytes. Xenobiotica 2004, 34 : 935-47. https://doi.org/10.1080/00498250400008363.

47. WOLKOFF AW. Organic Anion Uptake by Hepatocytes. Compr. Physiol., vol. 4, Hoboken, NJ, USA : John Wiley \& Sons, Inc., 2014, p. 1715-35. https://doi.org/10.1002/cphy.c140023.

48. HAGENBUCH B, MEIER P. Sinusoidal (Basolateral) Bile Salt Uptake Systems of Hepatocytes. Semin. Liver Dis. 1996, 16 : 129-36. https://doi org/10.1055/s-2007-1007226.

49. STIEGER B. The Role of the Sodium-Taurocholate Cotransporting Polypeptide (NTCP) and of the Bile Salt Export Pump (BSEP) in Physiology and Pathophysiology of Bile Formation. Handb. Exp. Pharmacol., 201, 2011, 205-59. https://doi.org/10.1007/978-3-642-14541-4_5.

50. STIEGER B, HAGENBUCH B. Organic Anion-Transporting Polypeptides Curr. Top. Membr., 73, 2014, 205-32. https://doi.org/10.1016/B978-0-12800223-0.00005-0.

51. KEPPLER D. Multidrug Resistance Proteins (MRPs, ABCCs) : Importance for Pathophysiology and Drug Therapy. Handb. Exp. Pharmacol., 201, 2011, 299-323. https://doi.org/10.1007/978-3-642-14541-4_8.

52. CIARIMBOLI G. Organic cation transporters. Xenobiotica 2008, 38 : 936 71. https://doi.org/10.1080/00498250701882482.

53. CAPERNA TJ, SHANNON AE, RICHARDS MP, GARRETT WM TALBOT NC. Identification and characterization of aquaporin-9 (AQP9) in porcine hepatic tissue and hepatocytes in monolayer culture. Domest. Anim. Endocrinol. 2007, 32 : 273-86. https://doi.org/10.1016/j. domaniend.2006.03.008

54. ZIMNIAK P, AWASTHI YC. ATP-dependent transport systems for organic anions. Hepatology 1993, 17 : 330-9. https://doi.org/10.1002/hep. 1840170226

55. DAWSON PA, LAN T, RAO A. Bile acid transporters. J. Lipid. Res. 2009 50 : 2340-57. https://doi.org/10.1194/jlr.R900012-JLR200.

56. JETTER A, KULLAK-UBLICK GA. Drugs and hepatic transporters : A review. Pharmacol. Res. 2020, 154 : 104234. https://doi.org/10.1016/j.phrs. 2019.04.018.

57. SILVERMAN JA, SCHRENK D. Expression of the multidrug resistance genes in the liver. FASEB J. 1997, 11: 308-13. https://doi.org/10.1096/ fasebj.11.5.9141496.

58. GONZALES E. Liver diseases related to MDR3 (ABCB4) gene deficiency. Front. Biosci. 2009, Volume : 4242. https://doi.org/10.2741/3526.

59. CROCENZI F, MOTTINO A, ROMA M. Regulation of Synthesis and Trafficking of Canalicular Transporters and its Alteration in Acquired Hepatocellular Cholestasis. Experimental Therapeutic Strategies for its Prevention. Curr. Med. Chem. 2004, 11: 501-24. https://doi.org/10. 2174/0929867043455918.

60. TOGAWA T, MIZUOCHI T, SUGIURA T, KUSANO H, TANIKAWA K, SASAKI T, et al. Clinical, Pathologic, and Genetic Features of Neonatal
Dubin-Johnson Syndrome : A Multicenter Study in Japan. J. Pediatr. 2018, 196 : 161-167.e1. https://doi.org/10.1016/j.jpeds.2017.12.058.

61. KÖNIG J, NIES AT, CUI Y, LEIER I, KEPPLER D. Conjugate export pumps of the multidrug resistance protein (MRP) family: localization, substrate specificity, and MRP2-mediated drug resistance. Biochim. Biophys. Acta Biomembr. 1999, 1461: 377-94. https://doi.org/10.1016/S0005-2736 (99)00169-8.

62. KEPPLER D, CUI Y, KÖNIG J, LEIER I, NIES A. Export pumps for anionic conjugates encoded by MRP genes. Adv. Enzyme Regul. 1999, 39 : 237-46. https://doi.org/10.1016/S0065-2571(98)00015-6.

63. BRUCK R, BENEDETTI A, STRAZZABOSCO M, BOYER JL. Intracellular alkalinization stimulates bile flow and vesicular-mediated exocytosis in IPRL. Am. J. Physiol. Liver Physiol. 1993, 265 : G347-53. https://doi.org/10.1152/ ajpgi.1993.265.2.G347.

64. CHAN J, VANDEBERG JL. Hepatobiliary transport in health and disease. Clin. Lipidol. 2012, 7 : 189-202. https://doi.org/10.2217/clp.12.12.

65. WANG R, SALEM M, YOUSEF IM, TUCHWEBER B, LAM P, CHILDS $\mathrm{SJ}$, et al. Targeted inactivation of sister of P-glycoprotein gene (spgp) in mice results in nonprogressive but persistent intrahepatic cholestasis. Proc. Natl. Acad. Sci. 2001, 98 : 2011-6. https://doi.org/10.1073/pnas.98.4.2011.

66. KUBITZ R, DRÖGE C, STINDT J, WEISSENBERGER K, HÄUSSINGER D. The bile salt export pump (BSEP) in health and disease. Clin. Res. Hepatol. Gastroenterol. 2012, 36 : 536-53. https://doi.org/10.1016/j.clinre. 2012.06.006

67. LAM P, SOROKA C, BOYER J. The Bile Salt Export Pump : Clinical and Experimental Aspects of Genetic and Acquired Cholestatic Liver Disease. Semin. Liver Dis. 2010, 30 : 125-33. https://doi.org/10.1055/s-0030-1253222.

68. GROEN A, ROMERO MR, KUNNE C, HOOSDALLY SJ, DIXON PH, WOODING C, et al. Complementary Functions of the Flippase ATP8B1 and the Floppase ABCB4 in Maintaining Canalicular Membrane Integrity. Gastroenterology 2011, 141 : 1927-1937.e4. https://doi.org/10.1053/j.gastro. 2011.07.042.

69. CAI S, GAUTAM S, NGUYEN T, SOROKA CJ, RAHNER C, BOYER JL. ATP8B1 Deficiency Disrupts the Bile Canalicular Membrane Bilayer Structure in Hepatocytes, But FXR Expression and Activity Are Maintained. Gastroenterology 2009, 136 : 1060-1069.e4. https://doi.org/10.1053/j.gastro. 2008.10 .025

70. VERHULST PM, VAN DER VELDEN LM, OORSCHOT V, VAN FAASSEN EE, KLUMPERMAN J, J. HOUWEN RH, et al. A flippaseindependent function of ATP8B1, the protein affected in familial intrahepatic cholestasis type 1, is required for apical protein expression and microvillus formation in polarized epithelial cells. Hepatology 2010, 51 : 2049-60. https://doi.org/10.1002/hep.23586.

71. VAN DER MARK VA, DE WAART DR, HO-MOK KS, TABBERS MM, VOOGT HW, OUDE ELFERINK RPJ, et al. The lipid flippase heterodimer ATP8B1-CDC50A is essential for surface expression of the apical sodiumdependent bile acid transporter (SLC10A2/ASBT) in intestinal Caco-2 cells. Biochim. Biophys. Acta - Mol. Basis Dis. 2014, 1842 : 2378-86. https://doi. org/10.1016/j.bbadis.2014.09.003.

72. ARRESE M, MACIAS RIR, BRIZ O, PEREZ MJ, MARIN JJG. Molecular pathogenesis of intrahepatic cholestasis of pregnancy. Expert Rev. Mol. Med. 2008, 10 : e9. https://doi.org/10.1017/S1462399408000628.

73. RODRÍGUEZ-GARAY EA. Cholestasis : human disease and experimental animal models. Ann. Hepatol. n.d., 2 : 150-8.

74. LINDBERG MC. Hepatobiliary complications of oral contraceptives. J. Gen Intern. Med. 1992, 7 : 199-209. https://doi.org/10.1007/BF02598014.

75. REYES H. Sex hormones and bile acids in intrahepatic cholestasis of pregnancy. Hepatology 2008, 47 : 376-9. https://doi.org/10.1002/hep.22139.

76. SONG X, VASILENKO A, CHEN Y, VALANEJAD L, VERMA R, YAN B, et al. Transcriptional dynamics of bile salt export pump during pregnancy : Mechanisms and implications in intrahepatic cholestasis of pregnancy. Hepatology 2014, 60 : 1993-2007. https://doi.org/10.1002/hep.27171.

77. SCHREIBER AJ, SIMON FR. Estrogen-Induced Cholestasis: Clues to Pathogenesis and Treatment. Hepatology 2007, 3 : 607-13. https://doi.org/10. 1002/hep.1840030422.

78. MAKISHIMA M. Identification of a Nuclear Receptor for Bile Acids. Science (80- ) 1999, 284 : 1362-5. https://doi.org/10.1126/science.284.5418.1362.

79. PARKS DJ. Bile Acids : Natural Ligands for an Orphan Nuclear Receptor. Science (80- ) 1999, 284 : 1365-8. https://doi.org/10.1126/science.284.5418. 1365 .

80. WANG H, CHEN J, HOLLISTER K, SOWERS LC, FORMAN BM Endogenous Bile Acids Are Ligands for the Nuclear Receptor FXR/BAR. Mol. Cell 1999, 3 : 543-53. https://doi.org/10.1016/S1097-2765(00)80348-2.

81. CHEN Y, VASILENKO A, SONG X, VALANEJAD L, VERMA R, YOU $\mathrm{S}$, et al. Estrogen and Estrogen Receptor- $\alpha$-Mediated Transrepression of Bile Salt Export Pump. Mol. Endocrinol. 2015, 29 : 613-26. https://doi. org/10.1210/me.2015-1014. 
82. CHENG X, BUCKLEY D, KLAASSEN CD. Regulation of hepatic bile acid transporters Ntcp and Bsep expression. Biochem. Pharmacol. 2007, 74 : 1665-76. https://doi.org/10.1016/j.bcp.2007.08.014.

83. SOROKA CJ, BOYER JL. Biosynthesis and trafficking of the bile salt export pump, BSEP : Therapeutic implications of BSEP mutations. Mol. Aspects Med. 2014, 37 : 3-14. https://doi.org/10.1016/j.mam.2013.05.001.

84. CROCENZI FA, MOTTINO AD, CAO J, VEGGI LM, POZZI EJS, VORE $\mathrm{M}$, et al. Estradiol-17ß-D-glucuronide induces endocytic internalization of Bsep in rats. Am. J. Physiol. Liver Physiol. 2003, 285 : G449-59. https://doi. org/10.1152/ajpgi.00508.2002.

85. LAM P, XU S, SOROKA CJ, BOYER JL. A C-terminal tyrosine-based motif in the bile salt export pump directs clathrin-dependent endocytosis. Hepatology 2012, 55 : 1901-11. https://doi.org/10.1002/hep.25523.

86. HAYASHI H, INAMURA K, AIDA K, NAOI S, HORIKAWA R, NAGASAKA $\mathrm{H}$, et al. AP2 adaptor complex mediates bile salt export pump internalization and modulates its hepatocanalicular expression and transport function. Hepatology 2012, 55 : 1889-900. https://doi.org/10.1002/ hep. 25591.

87. STIEGER B, FATTINGER K, MADON J, KULLAK-UBLICK GA, MEIER PJ. Drug- and estrogen-induced cholestasis through inhibition of the hepatocellular bile salt export pump (Bsep) of rat liver. Gastroenterology 2000, 118 : 422-30. https://doi.org/10.1016/S0016-5085(00)70224-1.

88. MISZCZUK GS, BAROSSO IR, LAROCCA MC, MARRONE J, MARINELLI RA, BOAGLIO AC, et al. Mechanisms of canalicular transporter endocytosis in the cholestatic rat liver. Biochim. Biophys. Acta - Mol. Basis Dis. 2018, 1864 : 1072-85. https://doi.org/10.1016/j. bbadis.2018.01.015.

89. BOSSARD R, STIEGER B, O'NEILL B, FRICKER G, MEIER PJ. Ethinylestradiol treatment induces multiple canalicular membrane transport alterations in rat liver. J. Clin. Invest. 1993, 91 : 2714-20. https://doi.org/ 10.1172/JCI116511.

90. SIMON FR, FORTUNE J, IWAHASHI M, GARTUNG C, WOLKOFF A, SUTHERLAND E. Ethinyl estradiol cholestasis involves alterations in expression of liver sinusoidal transporters. Am. J. Physiol. Liver Physiol. 1996, 271 : G1043-52. https://doi.org/10.1152/ajpgi.1996.271.6.G1043.

91. GEIER A, DIETRICH CG, GERLOFF T, HAENDLY J, KULLAK-UBLICK GA, STIEGER B, et al. Regulation of basolateral organic anion transporters in ethinylestradiol-induced cholestasis in the rat. Biochim. Biophys. Acta Biomembr. 2003, 1609: 87-94. https://doi.org/10.1016/S0005-2736(02) 00657-0.

92. MOTTINO AD, HOFFMAN T, CROCENZI FA, SÁNCHEZ POZZI EJ, ROMA MG, VORE M. Disruption of function and localization of tight junctional structures and Mrp2 in sustained estradiol-17 $\beta-\langle\mathrm{scp}\rangle \mathrm{d}</ \mathrm{scp}\rangle$ -glucuronide-induced cholestasis. Am. J. Physiol. Liver Physiol. 2007, 293 : G391-402. https://doi.org/10.1152/ajpgi.00496.2006.

93. VALLEJO M, BRIZ O, SERRANO MA, MONTE MJ, MARIN JJG. Potential role of trans-inhibition of the bile salt export pump by progesterone metabolites in the etiopathogenesis of intrahepatic cholestasis of pregnancy. J. Hepatol. 2006, 44 : 1150-7. https://doi.org/10.1016/j.jhep.2005.09.017.

94. FERNÁNDEZ-MURGA ML, PETROV PD, CONDE I, CASTELL J V., GOMÉZ-LECHÓN MJ, JOVER R. Advances in drug-induced cholestasis : Clinical perspectives, potential mechanisms and in vitro systems. Food Chem. Toxicol. 2018, 120 : 196-212. https://doi.org/10.1016/j.fct.2018.07.017.

95. PADDA MS, SANCHEZ M, AKHTAR AJ, BOYER JL. Drug-induced cholestasis. Hepatology 2011, 53: 1377-87. https://doi.org/10.1002/hep. 24229.

96. FICKERT P, TRAUNER M, FUCHSBICHLER A, STUMPTNER C, ZATLOUKAL K, DENK H. Cytokeratins as Targets for Bile Acid-Induced Toxicity. Am. J. Pathol. 2002, 160 : 491-9. https://doi.org/10.1016/S00029440(10)64868-7.
97. BURBANK MG, BURBAN A, SHARANEK A, WEAVER RJ, GUGUENGUILLOUZO C, GUILLOUZO A. Early Alterations of Bile Canaliculi Dynamics and the Rho Kinase/Myosin Light Chain Kinase Pathway Are Characteristics of Drug-Induced Intrahepatic Cholestasis. Drug Metab. Dispos. 2016, 44 : 1780-93. https://doi.org/10.1124/dmd.116.071373.

98. PAULI-MAGNUS C, MEIER PJ. Hepatobiliary transporters and druginduced cholestasis. Hepatology 2006, 44 : 778-87. https://doi.org/10.1002/ hep. 21359 .

99. GARZEL B, YANG H, ZHANG L, HUANG S-M, POLLI JE, WANG H. The Role of Bile Salt Export Pump Gene Repression in Drug-Induced Cholestatic Liver Toxicity. Drug Metab. Dispos. 2014, 42 : 318-22. https:// doi.org/10.1124/dmd.113.054189.

100. LANG C, MEIER Y, STIEGER B, BEUERS U, LANG T, KERB R, et al. Mutations and polymorphisms in the bile salt export pump and the multidrug resistance protein 3 associated with drug-induced liver injury. Pharmacogenet. Genomics. 2007, 17 : 47-60. https://doi.org/10.1097/01. fpc.0000230418.28091.76.

101. DIXON PH. Heterozygous MDR3 missense mutation associated with intrahepatic cholestasis of pregnancy: evidence for a defect in protein trafficking. Hum. Mol. Genet. 2000, 9 : 1209-17. https://doi.org/10.1093/ hmg/9.8.1209.

102. KÖCK K, FERSLEW BC, NETTERBERG I, YANG K, URBAN TJ, SWAAN PW, et al. Risk Factors for Development of Cholestatic DrugInduced Liver Injury: Inhibition of Hepatic Basolateral Bile Acid Transporters Multidrug Resistance-Associated Proteins 3 and 4. Drug Metab. Dispos. 2014, 42 : 665-74. https://doi.org/10.1124/dmd.113.054304.

103. RIDLON JM, KANG DJ, HYLEMON PB, BAJAJ JS. Bile acids and the gut microbiome. Curr. Opin. Gastroenterol. 2014, 30 : 332-8. https://doi. org/10.1097/MOG.0000000000000057.

104. CRAWFORD JM, BOYER JL. Clinicopathology conferences : Inflammation-induced cholestasis. Hepatology 1998, 28 : 253-60. https:// doi.org/10.1002/hep.510280133.

105. BHOGAL HK. The molecular pathogenesis of cholestasis in sepsis. Front. Biosci. 2013, E5 : E598. https://doi.org/10.2741/E598.

106. KOSTERS A, KARPEN S. The Role of Inflammation in Cholestasis Clinical and Basic Aspects. Semin. Liver Dis. 2010, 30 : 186-94. https://doi. org $/ 10.1055 / \mathrm{s}-0030-1253227$

107. BOLDER U, TON-NU H, SCHTEINGART C, FRICK E, HOFMANN A. Hepatocyte transport of bile acids and organic anions in endotoxemic rats : Impaired uptake and secretion. Gastroenterology 1997, $112: 214-25$. https:// doi.org/10.1016/S0016-5085(97)70238-5.

108. ELFERINK MGL, OLINGA P, DRAAISMA AL, MEREMA MT, FABER $\mathrm{KN}$, SLOOFF MJH, et al. LPS-induced downregulation of MRP2 and BSEP in human liver is due to a posttranscriptional process. Am. J. Physiol. Liver Physiol. 2004, 287 : G1008-16. https://doi.org/10.1152/ajpgi.00071.2004.

109. JANSEN PLM, MÜLLER M. Early events in sepsis-associated cholestasis. Gastroenterology 1999, $\mathbf{1 1 6}$ : 486-8. https://doi.org/10.1016/S00165085(99)70147-2.

110. ZOLLNER G. Hepatobiliary transporter expression in percutaneous liver biopsies of patients with cholestatic liver diseases. Hepatology 2001, 33 633-46. https://doi.org/10.1053/jhep.2001.22646.

111. HUANG MJ, LIAW YF. Clinical associations between thyroid and liver diseases. J. Gastroenterol. Hepatol. 1995, 10 : 344-50. https://doi. org/10.1111/j.1440-1746.1995.tb01106.x.

112. LI L, DEHERAGODA M, LU Y, GONG J, WANG J. Hypothyroidism Associated with ATP8B1 Deficiency. J. Pediatr. 2015, 167 : 1334-1339.e1. https://doi.org/10.1016/j.jpeds.2015.08.037. 